\title{
Antidiabetic, Antilipidemic and Antioxidant Properties of Aqueous Extracts of Morinda Lucida and Nauclea Latifolia Leaves in Alloxan Induced Rats
}

\section{Folake Lucy Oyetayo ${ }^{1(\mathbb{D})}$, Olatunde Abass Oseni ${ }^{2}{ }^{(\mathbb{D})}$, Olapade Samuel Akinlolu ${ }^{1,3, *}$, Daniel Uwaremhevho Momodu ${ }^{3(1)}$}

1 Department of Biochemistry, Faculty of Science, Ekiti State University, Ekiti State, Nigeria; folake.oyetayo@eksu.edu.ng (F.L.O.);

2 Department of Medical Biochemistry, Faculty of Basic Medical Science, College of Medicine, Ekiti State University, AdoEkiti, Nigeria; olatunde.oseni@eksu.edu.ng (O.A.S.);

3 Department of Chemistry, Faculty of Science, Federal University Oye-Ekiti, Ekiti State, Nigeria; olapade.akinlolu@fuoye.edu.ng (O.S.A.); daniel.momodu@ fuoye.edu.ng (D.U.M.);

* Correspondence: olapade.akinlolu@ fuoye.edu.ng;

Received: 30.10.2020; Revised: 3.12.2020; Accepted: 7.12.2020; Published: 13.12.2020

Abstract: The study sought to evaluate the antidiabetic, antioxidants and hypolipidemic properties of Morinda lucida and Nauclea latifolia leaves in alloxan-induced diabetic rats. The rats used were grouped into six, including controls and standard drug groups. The body weights and blood glucose concentration of the animals were determined before and after induction of diabetes as well as after treatment with the aqueous extracts of the leaves. Superoxide dismutase, catalase, glutathione peroxidase, glutathione transferase, glutathione reductase, reduced glutathione, malondialdehyde, lipid profiles, and liver biomarker enzymes were also determined. The Morinda lucida and Nauclea latifolia extracts caused a significant reduction in the rats' glucose level after treatment. The status of reduced glutathione and antioxidants enzyme activities was significantly increased. However, the total cholesterol, low-density lipoprotein, triglyceride status showed reduction compare to the control. There was also a reduction in the concentration of malondialdehyde in the groups administered with Morinda lucida (2.88 \pm 0.00$)$ and with Nauclea latifolia leaves extracts $(3.85 \pm 0.12)$ compare to the diabetic control group (7.37 \pm 0.10$)$. The biomarker enzyme activities were relatively reduced in the group administered with the extracts of both plants. However, the leaves extract of the plants exhibits hypoglycemic, hypolipidemic, and antioxidant properties.

Keywords: Diabetic mellitus; hyperlipidemic; free-radicals; Morinda lucida; Nauclea latifolia.

(c) 2020 by the authors. This article is an open-access article distributed under the terms and conditions of the Creative Commons Attribution (CC BY) license (https://creativecommons.org/licenses/by/4.0/).

\section{Introduction}

Diabetes mellitus is a heterogeneous metabolic disorder characterized by insufficiency of insulin secretion and insulin receptor or post-receptor events with derangement in carbohydrate, protein, and lipid metabolisms resulting in chronic hyperglycemia with the fasting blood glucose concentration equal or greater than $140 \mathrm{mg} / \mathrm{dl}$ [1]. Insufficient insulin secretion caused by immune destruction of pancreatic $\beta$-cells leads to the development of insulin-dependent diabetes (Type 1). In the case of abnormal insulin cellular action, type- 2 diabetes is developed due to the gradual development of insulin resistance and pancreatic $\beta$ cell dysfunction. 
Diabetes mellitus is a rampant global epidemy of multifactorial etiology and risk predisposing factors such as the increasing aging population, genetic and environmental factors, fast-evolving, and increasing sedentary lifestyle and dietary changes [2,3]. Available statistics show that the global estimated prevalence for the disease stands at 285 million adults $(6.4 \%)$ of the world population in 2010. This figure is projected to rise to 439 million adults (7.7\%) by 2030 [4]. Diabetes prevalence is on the rise worldwide due to accumulating risk factors well pronounced in economically growing nations. An estimated 69\% rise is observed for the prevalence of the disease in adults in developing countries versus $20 \%$ for adults in developed countries [4-6]. The percentage of deaths attributable to high blood glucose or diabetes that occurs before age 70 is higher in low and middle-income countries than in highincome countries [7]. Most deaths are estimated to result from diabetes complications such as heart disease and stroke, neuropathy, nephropathy, cataracts, microangiopathy, atherosclerosis, and retinopathy [8].

Diabetes is a complex, chronic illness requiring continuous medical care with multifactorial risk-reduction strategies beyond glycemic control [9]. Mainstream drugs that are used to control diabetes fall into three main categories. The first category of drugs aims to enhance endogenous insulin availability. It includes agents that act on the sulfonylurea receptors in the pancreas to promote insulin secretion and others that impact the small intestinal mucosal epithelium. Medicines categorized as group two are directed to potentiate the insulin response, among them being thiazoline. This group of drugs seems to act as an initiator of peroxisomal receptors responsible for regulating the metabolism of carbohydrates, lipids, and proteins. The drugs categorized as group three are represented by $\alpha$-glycosidase inhibitors and are targeted at reducing complex sugars' metabolism [10-12].

Current glycemic medications burden patients due to variable contraindications and interactions with other drugs, limited efficacy, limited tolerability, and significant side effects arising from their complex action mechanisms [13-15]. Existing pharmacotherapy is still far from achieving optimal blood sugar control in such patients, as an effect of dysfunction in insulin secretion, action, or both. Several reviews from different countries have highlighted the significance of medicinal plant application to control diabetes [16-18]. In response to this global health challenge, the WHO Expert Committee on diabetes mellitus recommended further evaluation of the folkloric methods of managing the disease because of high mortality and morbidity arising from its attendant complications and drawbacks associated with using conventional antidiabetic drugs [18]. In pursuit of this goal, several medicinal plants are being investigated for their hypoglycemic efficacies.

Morinda lucida Benth. (Rubiaceae) is among several indigenous plants used in the local treatment of Diabetic Mellitus among Yorubas (South-West Nigeria). Different parts of the plant are attributed to diverse therapeutic benefits. Morinda lucida is a medium-sized tree used as a medicinal plant in West Africa (especially in Nigeria) in the local treatment of malaria and other febrile conditions, diabetes, hypertension, cerebral congestion, dysentery [19-26]. Different parts of the plant have been reported to possess antimicrobial [27]. The aqueous leaf extract of M. lucida has been reported to cause antidiabetic effects in streptozotocin-induced diabetic rats, while the ethanolic leaf extract of the same plant elicited antidiabetic effects in both normal and alloxan-induced diabetic rats [19].

Nauclea latifolia Smith (Rubiaceae) is a multi-stemmed shrub or small tree widespread in tropical Africa and Asia. The plant is used traditionally in the treatment of various diseases. In a part of Nigeria, the roots are used by some traditional medicine to treat hypertension [28]. 
The bark is used in the treatment of wounds, coughs, and gonorrhea in Nigeria. Biological activities reported on the roots include antibacterial, antifungal, anti-influenza, and antihyperlipidemic [29-32]. Therefore, this study sought to evaluate the comparative antidiabetic, antilipidemic and antioxidant properties of both $M$. lucida and $N$. latifolia aqueous extracts of their leaves in alloxan-induced rats.

\section{Materials and Methods}

\subsection{Collection of plant sample.}

Leaves of Morinda lucida and Nauclea latifolia were obtained from farmland and the Ifaki-Ikole town in Ekiti State, Nigeria, and authenticated with voucher number 2020044 and 2020045, respectively, at the University Herbarium, Department of Plant Science and Biotechnology, Ekiti State University, Nigeria. The leaves were air-dried and powdered using an electric blender.

\subsection{Animal sample.}

Adult male Wistar rats (100-150g) were obtained from Animals house of College of Medicine, Ekiti State University, Ado Ekiti, Nigeria. Animals were kept in separate animal cages, on a $12 \mathrm{hr}$ light/dark cycle at room temperature with free access to food and water. According to the National Institute of Health guide for the care and use of laboratory animals, the animals were used. Animals were placed into six groups of six rats each:

Group 1- Normal Control, fed with rat-feed and distilled water only.

Group 2- Diabetic Control (alloxan-induced), fed with rat-feed and distilled water;

Group 3- Standard Drug (metformin), fed with rat-feed and distilled water;

Group 4- Morinda lucida Leaf

Group 5- Nauclea latifolia Leaf

Group 6- Morinda lucida and Nauclea latifolia Leaves

After induction with alloxan, animals were observed for 72 hours, after which the glucose concentration levels have increased significantly before treated with $20 \mathrm{mg} / \mathrm{kg}$ body weight of aqueous leaves extracts of $M$. lucida and $N$. latifolia of both plants respectively for three weeks by oral administration. At the end of the experiment, animals were fasted 24 hours before sacrifice to obtain the blood for serum, liver, and kidney for organ homogenates.

\subsection{Extraction of crude active components.}

Dried powdered of M. lucida and N. latifolia leaves weighing $100 \mathrm{~g}$ each was extracted with $500 \mathrm{~mL}$ of distilled water for $72 \mathrm{~h}$. After that, the resulting mixture was filtered separately using a muslin cloth. The filtrates were left open for $72 \mathrm{~h}$ to allow for complete evaporation. The crude extract recovered after evaporation was stored separately in an airtight container in the refrigerator before use. Therefore, the crude extract was reconstituted in distilled water and administered to the animals orally for three weeks.

\subsection{Preparation of serum and tissue homogenates.}

At the end of three weeks, the animals were decapitated and dissected to obtain the blood, liver, and kidney. Whole blood was collected by cardiac puncture into a serum bottle. The serum was obtained by centrifugation at $3000 \mathrm{rpm}$ for $15 \mathrm{~min}$. Simultaneously, the 
homogenates of the liver and kidney were prepared by weighing $1 \mathrm{~g}$ in $10 \mathrm{~mL}$ of $6.7 \mathrm{mM}$ potassium phosphate buffer, $\mathrm{pH}$ 7.4, respectively, using Teflon homogenizer model 3431E10EA, Thomas Scientific, India. The tissue homogenate was centrifuged at 3,000 rpm for $10 \mathrm{~min}$ at $4^{\circ} \mathrm{C}$ to obtain a clear supernatant, kept at $8^{\circ} \mathrm{C}$ for subsequent analyses.

\subsection{Determination of alkaline phosphatase (ALP).}

Alkaline phosphatase was assayed following the method described by Brichacek and Brown [33], using a standard Fortress kit from England. Five hundred microliter $(500 \mu 1)$ of the substrate was equilibrium at $37^{\circ} \mathrm{C}$ for $3 \mathrm{~min}$. Fifty microliters $(50 \mu \mathrm{l})$ of the sample was added to the equilibrated substrate and incubated for $10 \mathrm{~min}$ at $37^{\circ} \mathrm{C} .2 .5 \mathrm{~mL}$ of color reagent (mixture of $\mathrm{NaOH}, 0.09 \mathrm{M}$ and $\mathrm{Na}_{2} \mathrm{CO}_{3}, 0.1 \mathrm{M}$ ) was added. This mixture was thoroughly mixed. The absorbance of the sample against the blank was read at $590 \mathrm{~nm}$. ALP (IU/L) was then calculated.

\subsection{Determination of aspartate transaminase (AST).}

Aspartate transaminase AST was assayed following the method described by Brichacek and Brown [33], using a standard Fortress kit from England. Briefly, 100 $\mu$ of homogenate was added to $500 \mu 1$ of AST buffer, thoroughly mixed, and incubated for $30 \mathrm{~min}$ at $37^{\circ} \mathrm{C}$. After that, $0.5 \mathrm{ml}$ of dye reagent (2,4-dinitrophenyl hydrazine, $(2.0 \mathrm{mM})$ was added, and the mixture was thoroughly mixed and allowed to stand for $20 \mathrm{~min}$ at $20{ }^{\circ} \mathrm{C}$. Five milliliters $(5.0 \mathrm{ml})$ of $0.01 \mathrm{M}$ $\mathrm{NaOH}$ was then added and thoroughly mixed., The absorbance of the sample against the blank was read at $546 \mathrm{~nm}$.

\subsection{Determination of alanine transferase (ALT).}

ALT was measured using a standard Fortress kit from England according to the method of the International Federation of Clinical Chemistry (1986) using a standard Fortress kit from England. One hundred microliters $(100 \mu \mathrm{l})$ of homogenates were added to $500 \mu \mathrm{l}$ of ALT buffer, thoroughly mixed, and incubated for $30 \mathrm{~min}$ at $37^{\circ} \mathrm{C}$ in a water bath. Five hundred microliters $(500 \mu \mathrm{l})$ of dye reagent $(2$, 4-dinitrophenyl hydrazine, $2.0 \mathrm{mM})$ was then added. This mixture was thoroughly mixed and allowed to stand for $20 \mathrm{~min}$ at $20^{\circ} \mathrm{C}$. After that, $5.0 \mathrm{ml}$ of diluted $\mathrm{NaOH}$ was then added and thoroughly mixed. The absorbance of the resulting mixture sample against the blank was read at $546 \mathrm{~nm}$.

\subsection{Determination of Superoxide dismutase (SOD).}

Superoxide dismutase activity in both serum and tissue homogenates was determined by the method of Molehin et al. [34], using a standard Fortress kit from England. An aliquot of the serum and/or tissue homogenates was added to $2.5 \mathrm{ml}$ of $0.05 \mathrm{M}$ carbonate buffer, $\mathrm{pH}$ 10.2. The mixture was allowed to equilibrate for $2 \mathrm{~min}$ in a spectrophotometer. The reaction was then started by adding $0.3 \mathrm{ml}$ of freshly prepared $0.3 \mathrm{mM}$ adrenaline to the mixture, which was quickly mixed by inversion. The reference cuvette contained all other assay components except the homogenate(s) and/or serum replaced with distilled water. An increase in absorbance at $480 \mathrm{~nm}$ was monitored every $30 \mathrm{sec}$ for $150 \mathrm{sec}$. 


\subsection{Determination of catalase activities (CAT).}

Catalase activity in the serum and tissue homogenates were determined as described by Igile et al. [35], using a standard Fortress kit from England. Two hundred microliters (200 $\mu \mathrm{l})$ of tissue homogenates were mixed with $0.8 \mathrm{ml}$ distilled $\mathrm{H}_{2} \mathrm{O}$ to give $\mathrm{I}$ in 5 dilutions of the sample. Five hundred microliters $(500 \mu \mathrm{l})$ of tissue homogenate was rapid, mixed with the reaction mixture at room temperature by a gentle swirling. One milliliter $(1 \mathrm{ml})$ portion of the reaction mixture was withdrawn and blown into $1 \mathrm{ml}$ dichromate/acetic acid reagent at 60 seconds. The hydrogen peroxide content of the withdrawn sample was determined by the method described above at $570 \mathrm{~nm}$.

\subsection{Determinations of HDL-cholesterol.}

HDL-cholesterol was measured following the method described by Baggio and Bragagnolo [36], using standard Fortree from England. Briefly, $5 \mu 1$ of homogenate was added to $450 \mu 1$ of Good's buffer (4-amino antipyrine, POD, ascorbic oxidase, and anti-human lipoprotein $\mathrm{Ab}$ ). This mixture was mixed well 5 and incubated at $37^{\circ} \mathrm{C}$ in a water bath for $5 \mathrm{~min}$. Thereafter, $150 \mu 1$ of enzyme reagent (Good's buffer 1, cholesterol esterase, and cholesterol oxidase) was later added to the mixture and incubated for $5 \mathrm{~min}$ at $37^{\circ} \mathrm{C}$. The absorbance of the resulting mixture was then read against the blank at $600 \mathrm{~nm}$.

\subsection{Determination of $L D L-$ cholesterol}

Low-density lipoprotein - cholesterol (LDL-chol) was determined by the method earlier described by Baggio and Bragagnolo [36], using a standard Fortress kit from England. Briefly, $5 \mu$ of tissue homogenate was added to $450 \mu$ l of buffer solution (Good's buffer, and peroxidase). This mixture was mixed well and incubated at $37^{\circ} \mathrm{C}$ in a water bath for $5 \mathrm{~min}$. Absorbance 1 was measured at $600 \mathrm{~nm}$. One hundred and fifty microliters $(150 \mu \mathrm{l})$ of enzyme reagent R2 (Amino antipyrine and POD) was later added to the mixture and incubated for 5 min at $37^{\circ} \mathrm{C}$. Absorbance 2 of the sample against the blank was read at $600 \mathrm{~nm}$.

\subsection{Determination of total cholesterol.}

Total cholesterol in the serum and tissue homogenates was routinely determined following [35,36], using a standard Fortress kit from England. Ten microliters (10 $\mu 1)$ of tissue homogenate was thoroughly mixed with $1 \mathrm{ml}$ of working reagent (4-amino antipyrine, cholesterol oxidase, cholesterol esterase, and peroxidase dissolved in $50 \mathrm{ml}$ of pipes buffer and phenol). The reaction mixture was incubated for $10 \mathrm{~min}$ at $25^{\circ} \mathrm{C}$. The absorbance of the sample against the blank was read at $546 \mathrm{~nm}$. Total cholesterol $(\mathrm{nm})$ concentration was then calculated by the equation: [(Abs. x 200) $\div(0.042)]$.

\subsection{Determination of lipid peroxidation assay (TBARS).}

Levels of the thiobarbituric acid reactive species (TBARS) in the tissues and serum homogenates were measured according to the method of Steghens et al. [37], using standard Fortress from England. An aliquot of $0.4 \mathrm{ml}$ of serum and other tissue homogenates was mixed with $1.6 \mathrm{ml}$ of Tris- $\mathrm{KCl}$ buffer. It was added to which $0.5 \mathrm{ml}$ of $30 \%$ trichloroacetic acid (TCA). After that, $0.5 \mathrm{ml}$ of $0.75 \%$ thiobarbituric acid (TBA) was added and incubated for $45 \mathrm{~min}$ at $80{ }^{\circ} \mathrm{C}$. The resulting mixture was then cooled on ice and centrifuged at $3000 \mathrm{rpm}$. The clear 
supernatant was collected and absorbance measured against a reference blank at $532 \mathrm{~nm}$. The MDA level was calculated according to the method of [38].

\subsection{Determination of total protein.}

Total protein content was determined using the Biuret method Al-Attar [39] using a standard Fortress kit from England. Briefly, $20 \mathrm{ml}$ of homogenate was thoroughly mixed with $1 \mathrm{ml}$ of Biuret reagent and incubated at room temperature for $10 \mathrm{~min}$. The absorbance of the resulting mixture was read at $546 \mathrm{~nm}$ against the blank.

\subsection{Determination of total phenolic contents.}

The total phenolic contents were determined spectrophotometrically using the FolinCiocalteu reagent reported by Daay and Lattanzio [40]. The extracts were reacted with FolinCiocalteu reagent and then neutralized with sodium carbonate solution (25\%). After $2 \mathrm{~h}$, the absorbance of the resulting solution was measured at $765 \mathrm{~nm}$. The concentrations of phenolic compounds were calculated according to the equation obtained from the standard as a gallic acid graph: Absorbance $=[0.0007 \times$ gallic acid $(\mu \mathrm{g})+0.0642]$, with $\mathrm{R}^{2}=0.9964$.

All tests were carried out in triplicate, and the results are given as gallic acid equivalents (GAE) per g of dry extract.

\subsection{Determination of total flavonoid contents.}

Total flavonoid contents were determined using the Dowd method adapted by, Daay and Lattanzio [40]. $1 \mathrm{~mL}$ of $2 \%$ aluminum trichloride $\left(\mathrm{AlCl}_{3}\right)$ in methanol was mixed with the same volume of the methanolic extracts $(2000 \mu \mathrm{g})$. Absorption readings at $415 \mathrm{~nm}$ were taken after 10 min against a blank sample consisting of a $1 \mathrm{~mL}$ extract solution with $1 \mathrm{~mL}$ methanol without $\mathrm{AlCl}_{3}$. The concentrations of flavonoid compounds were calculated according to the equation obtained from the standard quercetin graph:

Absorbance $=[0.0333 \times$ quercetin $(\mu \mathrm{g})+0.0231]$, with $\mathrm{R}^{2}=0.9961$.

\subsection{Statistical analysis.}

The data obtained from the study were analyzed using one-way analysis of variance (ANOVA) followed by post-hoc Duncan test and expressed as mean \pm SD (standard deviation) with a $\mathrm{p}$-value less than $0.05(\mathrm{p}<0.05)$ considered to be statistically significant.

\section{Results and Discussion}

In this present study, experimental diabetes was reliably established in the rats intraperitoneally when injected with alloxan monohydrate, which was characterized by hyperglycemia that was sustained throughout the three weeks of treatment as demonstrated in the untreated diabetic rats.

In Tables 1 and 2, the mean weight gain was high in groups that received both the extracts and the standard drug than the normal, which may be due to the extracts' beneficial effect. After the consumption of the extracts, animals showed a slight increase in weight gain. Diabetes was fully established in Table 2 , as evidenced by the significant $(\mathrm{p}<0.05)$ elevation in the Fasting blood glucose concentrations in the negative control. However, oral treatment with M. lucida and N. latifolia extracts for twenty-one consecutive days significantly $(\mathrm{p}<0.05)$ 
lowered the Fasting blood glucose level from $452.5 \pm 2.50 \mathrm{M}$. Lucida group to $249.0 \pm 1.00$. $N$. Latifolia group extract also significantly reduced the blood sugar in group five from (502.0 $\pm 1.00)$ to $(104.0 \pm 1.00)$ close to the normal. The Fasting blood-glucose-lowering effect of $M$. lucida and $N$. latifolia was significantly $(\mathrm{p}<0.05)$ higher than that of metformin.

The observed hypoglycemic effect of M. lucida and N. latifolia is an indication that the two plants contain active components with the potent hypoglycemic property. In normal rats, they could be acting via increased insulin secretion or increased peripheral utilization of glucose, but in the in vivo type II diabetes model created in this study, the two extracts lower hyperglycemia by increasing the peripheral utilization of glucose in the diabetic rats.

In this study, continuous synergetic treatment with the leaves extract of M. lucida and N. latifolia for 3 weeks caused a significant decrease in the blood glucose level of treated rats compared to untreated diabetic rats seen in Table 3. A corresponding increase followed this in the bodyweight of the treated rats. Diabetes is characterized by a severe loss in body weight due to the loss or degradation of structural proteins [41]. This condition was alleviated by the treatment of diabetic rats with leaf extracts of Morinda lucida and Nauclea latifolia. Some plant extracts are reported to exert hypoglycemic action by potentiating the insulin effect, either by increasing the pancreatic secretion of insulin from the cells of islets of Langerhans or its release from bound insulin. In contrast, others act through extrapancreatic mechanisms by inhibiting hepatic glucose production or corrections of insulin resistance. This study's result is in consonance with that reported for the dried leaves extract of Morinda lucida Benth in normal and streptozotocin-diabetic rats [42].

Some phytochemical compounds such as saponin, terpenes and tannins, steroids, and alkaloids have been implicated in plants' antidiabetic activities. Phytochemical study of the leaves extracts revealed the presence of terpenes, saponins, tannins flavonoids, and alkaloids, as shown in Table 1.

Table 1. Phytochemical screening of aqueous leaves extracts of M. lucida and N. latifolia.

\begin{tabular}{|c|c|c|c|c|c|}
\hline Plant Part & Tannin & Terpenoid & Alkanoid & Saponin & Glycoside \\
\hline Morinda Lucida leaf & 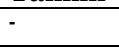 & + & + & ++ & ++ \\
\hline Nauclea Latifolia leaf & + & + & + & ++ & ++ \\
\hline
\end{tabular}

Table 2. Effects of aqueous leaves extract of M. lucida and N. latifolia on diabetic Rats weights (g).

\begin{tabular}{|c|c|c|c|c|c|c|}
\hline Category & Group 1 & Group 2 & Group 3 & Group 4 & Group 5 & Group 6 \\
\hline Before Alloxan Induction & $161.50 \pm 0.50^{\mathrm{a}}$ & $144.50 \pm 0.50^{\mathrm{b}}$ & $173.50 \pm 0.50^{c}$ & $150.50 \pm 0.50^{\mathrm{d}}$ & $164.50 \pm 0.50^{\mathrm{a}}$ & $156.50 \pm 0.50^{\mathrm{d}}$ \\
\hline After Alloxan Induction & $166.50 \pm 0.50^{\mathrm{a}}$ & $154.00 \pm 1.00^{\mathrm{b}}$ & $159.50 \pm 0.50^{\mathrm{ac}}$ & $127.00 \pm 1.00^{\mathrm{d}}$ & $121.00 \pm 1.00^{\mathrm{d}}$ & $156.5 \pm 0.50^{\mathrm{b}}$ \\
\hline $\begin{array}{l}\text { After } \\
\text { Treatments }\end{array}$ & $181.00 \pm 1.50^{\mathrm{a}}$ & $136.50 \pm 0.50^{\mathrm{b}}$ & $188.50 \pm 0.50^{\mathrm{a}}$ & $191.00 \pm 1.50^{\mathrm{c}}$ & $186.50 \pm 0.50^{\mathrm{a}}$ & $101.00 \pm 1.00^{\mathrm{d}}$ \\
\hline \multicolumn{7}{|c|}{$\begin{array}{l}\text { Values are expressed as mean } \pm \text { SD. Values with different superscript letters indicate differences among the groups } \\
(P<0.05) \text {. Group 1: Normal Control; Group 2: Diabetic Control; Group 3: Standard Drug; Group 4: Morinda } \\
\text { lucida Leaf; Group 5: Nauclea latifolia Leaf; Group 6: M. lucida and N. latifolia Leaves. }\end{array}$} \\
\hline
\end{tabular}

Table 3. Effect of aqueous leaf extracts of M. lucida and N. latifolia on fasting blood sugar concentration in diabetic rats $(\mathrm{mg} / \mathrm{L})$.

\begin{tabular}{l|l|l|l|l|l|l} 
Category & Group 1 & Group 2 & Group 3 & Group 4 & Group 5 & Group 6 \\
\hline $\begin{array}{l}\text { Before Alloxan } \\
\text { Induction }\end{array}$ & $107.50 \pm 2.50^{\mathrm{a}}$ & $83.50 \pm 1.50^{\mathrm{b}}$ & $112.50 \pm 0.50^{\mathrm{c}}$ & $94.00 \pm 1.00^{\mathrm{d}}$ & $104.00 \pm 1.00^{\mathrm{a}}$ & $88.50 \pm 1.50^{\mathrm{b}}$ \\
\hline $\begin{array}{l}\text { After Alloxan } \\
\text { Induction }\end{array}$ & $103.00 \pm 2.00^{\mathrm{a}}$ & $328.50 \pm 1.50^{\mathrm{b}}$ & $283.50 \pm 0.50^{\mathrm{c}}$ & $452.50 \pm 2.50^{\mathrm{d}}$ & $502.00 \pm 1.00^{\mathrm{e}}$ & $471.50 \pm 1.00^{\mathrm{d}}$ \\
\hline $\begin{array}{l}\text { After } \\
\text { Treatments }\end{array}$ & $102.00 \pm 1.00^{\mathrm{a}}$ & $209.50 \pm 0.50^{\mathrm{b}}$ & $108.00 \pm 1.00^{\mathrm{a}}$ & $249.00 \pm 1.00^{\mathrm{c}}$ & $104.00 \pm 1.00^{\mathrm{a}}$ & $327.50 \pm 2.50^{\mathrm{d}}$
\end{tabular}

Values are expressed as mean \pm SD. Values with different superscript letters indicate differences among the groups $(P<0.05)$. Group 1: Normal Control; Group 2: Diabetic Control; Group 3: Standard Drug; Group 4: Morinda lucida Leaf; Group 5: Nauclea latifolia Leaf; Group 6: M. lucida and N. latifolia Leaves. 
The presence of indole alkaloids in the root of Nauclea latifolia has been reported to exert antidiabetic activity [43]. In part, these constituents may be responsible for the observed significant activity of this extract either singly or in synergy with M. lucida. Equally, Olajide et al. [42] and Lawal et al. [44] independently reported Morinda leaves to contain high concentrations of flavonoids, alkaloids, tannins, and saponin. Hyperlipidemia contributes to major risk factors of cardiovascular diseases [45].

Diabetes has been related to oxidative stress either as a causative factor or because of its consequence [46]. Alloxan-induced diabetes is characterized by impaired glucose tolerance and hyperglycemia and the collapse in the antioxidant defense mechanism. Oxidative stress has been shown to be responsible, at least in part, for tissue damage and beta-cell dysfunction [47]. Reactive oxygen species (ROS) produced by alloxan administration may lead to DNA fragmentation and other deleterious changes in the cells [48]. In the present study, alloxan administration induced a collapse in antioxidant defense as observed in a decrease in SOD, CAT activities and an increase in lipid peroxidation product (MDA) in the diabetic control group as seen from Table 4 to 9 . In order to reduce the effect of alloxan, SOD catalyzes the dismutation of the superoxide radical, and the CAT removes the product of the SOD ( which is hydrogen peroxide) from circulation. The enzymes SOD and CAT are major antioxidant defense system of the body, which protect the cell membrane and other cellular constituents against oxidative damage by free ROS [49]. Both the extract and the standard drug (metformin) prevented the collapse in antioxidant defense by maintaining the SOD, CAT, and MDA towards normal. Earlier reports portrayed methanolic extract of the stem bark of M. lucida as having radical scavenging activities in-vitro [50].

Table 4. Effect of aqueous extract of M. lucida and N. latifolia leaves on Catalase activities in diabetic rats $(\mathrm{U} / \mathrm{L})$.

\begin{tabular}{l|l|l|l|l|l|l} 
Category & Group 1 & Group 2 & Group 3 & Group 4 & Group 5 & Group 6 \\
\hline Serum & $16.44 \pm 0.00^{\mathrm{a}}$ & $2.96 \pm 0.01^{\mathrm{b}}$ & $25.96 \pm 0.01^{\mathrm{c}}$ & $15.77 \pm 0.01^{\mathrm{a}}$ & $3.96 \pm 0.01^{\mathrm{d}}$ & $4.09 \pm 0.00^{\mathrm{d}}$ \\
\hline Liver & $0.03 \pm 0.02^{\mathrm{a}}$ & $0.49 \pm 0.02^{\mathrm{b}}$ & $0.74 \pm 0.01^{\mathrm{c}}$ & $0.14 \pm 0.02^{\mathrm{d}}$ & $1.01 \pm 0.02^{\mathrm{e}}$ & $0.16 \pm 0.02^{\mathrm{d}}$ \\
\hline Kidney & $0.28 \pm 0.01^{\mathrm{a}}$ & $0.20 \pm 0.02^{\mathrm{a}}$ & $0.63 \pm 0.01^{\mathrm{b}}$ & $0.67 \pm 0.01^{\mathrm{b}}$ & $0.36 \pm 0.00^{\mathrm{a}}$ & $0.14 \pm 0.02^{\mathrm{a}}$
\end{tabular}

Values are expressed as mean \pm SD. Values with different superscript letters indicate differences among the groups $(P<0.05)$. Group 1: Normal Control; Group 2: Diabetic Control; Group 3: Standard Drug; Group 4: Morinda lucida Leaf; Group 5: Nauclea latifolia Leaf; Group 6: M. lucida and N. latifolia Leaves.

Table 5. Effect of aqueous extract of M. lucida and N. latifolia on Superoxide Dismutase (SOD) activities in diabetic rats (U/L).

\begin{tabular}{l|l|l|l|l|l|l} 
Category & Group 1 & Group 2 & Group 3 & Group 4 & Group 5 & Group 6 \\
\hline Serum & $4.80 \pm 0.01^{\mathrm{a}}$ & $1.80 \pm 0.00^{\mathrm{b}}$ & $3.20 \pm 0.02^{\mathrm{c}}$ & $3.40 \pm 0.01^{\mathrm{c}}$ & $2.20 \pm 0.00^{\mathrm{b}}$ & $3.40 \pm 0.01^{\mathrm{c}}$ \\
\hline Liver & $5.60 \pm 0.02^{\mathrm{a}}$ & $0.60 \pm 0.00^{\mathrm{b}}$ & $4.20 \pm 0.01^{\mathrm{c}}$ & $4.40 \pm 0.01^{\mathrm{c}}$ & $2.20 \pm 0.02^{\mathrm{d}}$ & $2.10 \pm 0.01^{\mathrm{d}}$ \\
\hline Kidney & $3.80 \pm 0.00^{\mathrm{a}}$ & $1.20 \pm 0.01^{\mathrm{b}}$ & $3.80 \pm 0.02^{\mathrm{a}}$ & $1.80 \pm 0.02^{\mathrm{c}}$ & $1.40 \pm 0.01^{\mathrm{b}}$ & $0.90 \pm 0.01^{\mathrm{d}}$
\end{tabular}

Values are expressed as mean \pm SD. Values with different superscript letters indicate differences among the groups $(P<0.05)$. Group 1: Normal Control; Group 2: Diabetic Control; Group 3: Standard Drug; Group 4: Morinda lucida Leaf; Group 5: Nauclea latifolia Leaf; Group 6: M. lucida and N. latifolia Leaves.

Table 6. Effect of aqueous extract of M. lucida and N. latifolia on Malonyldialdehyde (MDA) activities in

\begin{tabular}{l|l|l|l|l|l|l}
\multicolumn{8}{c}{ diabetic rats $(\mu \mathrm{M})$. } \\
Category & Group 1 & Group 2 & Group 3 & Group 4 & GrouP 5 & Group 6 \\
\hline Serum & $2.56 \pm 0.17^{\mathrm{a}}$ & $7.37 \pm 0.10^{\mathrm{b}}$ & $1.92 \pm 0.10^{\mathrm{c}}$ & $2.88 \pm 0.00^{\mathrm{a}}$ & $3.85 \pm 0.12^{\mathrm{d}}$ & $2.18 \pm 0.15^{\mathrm{a}}$ \\
\hline Liver & $2.56 \pm 0.00^{\mathrm{a}}$ & $14.23 \pm 0.10^{\mathrm{b}}$ & $14.13 \pm 0.10^{\mathrm{b}}$ & $17.79 \pm 0.00^{\mathrm{c}}$ & $26.28 \pm 0.10^{\mathrm{d}}$ & $2.18 \pm 0.15^{\mathrm{a}}$ \\
\hline Kidney & $8.97 \pm 0.17^{\mathrm{a}}$ & $16.25 \pm 0.10^{\mathrm{b}}$ & $20.71 \pm 0.10^{\mathrm{c}}$ & $23.39 \pm 0.10^{\mathrm{c}}$ & $16.63 \pm 0.10^{\mathrm{b}}$ & $16.19 \pm 0.15^{\mathrm{b}}$
\end{tabular}

Values are expressed as mean \pm SD. Values with different superscript letters indicate differences among the groups $(P<0.05)$. Group 1: Normal Control; Group 2: Diabetic Control; Group 3: Standard Drug; Group 4: Morinda lucida Leaf; Group 5: Nauclea latifolia Leaf; Group 6: M. lucida and N. latifolia Leaves.

Thus, plant extract or metformin's presence prevented the build-up of oxidative stress and allowed for the recovery from antioxidant collapse. The ability of M. lucida and N. latifolia 
leaves extracts to prevent the alteration of antioxidants status may be due to phenolic content and other phytochemical compounds present [51].

Table 7. Effect of aqueous extract of M. lucida and N. latifolia leaves on Gluthathione transferase activities in

\begin{tabular}{l|l|l|l|l|l|l} 
Category & Group 1 & Group 2 & Group 3 & Group 4 & Group 5 & Group 6 \\
\hline Serum & $2.95 \pm 0.00^{\mathrm{a}}$ & $1.01 \pm 0.00^{\mathrm{b}}$ & $1.55 \pm 0.00^{\mathrm{c}}$ & $1.85 \pm 0.00^{\mathrm{d}}$ & $1.25 \pm 0.00^{\mathrm{e}}$ & $1.35 \pm 0.09^{\mathrm{e}}$ \\
\hline Liver & $2.55 \pm 0.00^{\mathrm{a}}$ & $1.13 \pm 0.00^{\mathrm{b}}$ & $1.28 \pm 0.00^{\mathrm{c}}$ & $1.26 \pm 0.00^{\mathrm{c}}$ & $1.23 \pm 0.00^{\mathrm{c}}$ & $1.16 \pm 0.00^{\mathrm{b}}$ \\
\hline Kidney & $2.90 \pm 0.00^{\mathrm{a}}$ & $1.07 \pm 0.00^{\mathrm{b}}$ & $1.17 \pm 0.00^{\mathrm{c}}$ & $2.14 \pm 0.00^{\mathrm{d}}$ & $1.10 \pm 0.00^{\mathrm{b}}$ & $2.00 \pm 0.00^{\mathrm{f}}$
\end{tabular}

Values are expressed as mean \pm SD. Values with different superscript letters indicate differences among the groups $(P<0.05)$. Group 1: Normal Control; Group 2: Diabetic Control; Group 3: Standard Drug; Group 4: Morinda lucida Leaf; Group 5: Nauclea latifolia Leaf; Group 6: M. lucida and N. latifolia Leaves.

Table 8. Effect of aqueous extract of M. lucida and N. latifolia leaves on Glutathione reductase activities in diabetic rats $(\mathrm{U} / \mathrm{L})$.

\begin{tabular}{l|l|l|l|l|l|l} 
Category & Group 1 & Group 2 & Group 3 & Group 4 & Group 5 & Group 6 \\
\hline Serum & $21.16 \pm 0.00^{\mathrm{a}}$ & $9.79 \pm 0.0^{\mathrm{b}}$ & $17.11 \pm 0.00^{\mathrm{c}}$ & $14.96 \pm 0.00^{\mathrm{d}}$ & $11.86 \pm 0.00^{\mathrm{e}}$ & $12.32 \pm 0.00^{\mathrm{e}}$ \\
\hline Liver & $30.95 \pm 0.01^{\mathrm{a}}$ & $15.56 \pm 0.00^{\mathrm{b}}$ & $18.67 \pm 0.01^{\mathrm{c}}$ & $18.45 \pm 0.00^{\mathrm{d}}$ & $21.83 \pm 0.00^{\mathrm{e}}$ & $24.65 \pm 0.00^{\mathrm{e}}$ \\
\hline Kidney & $41.52 \pm 0.00^{\mathrm{a}}$ & $35.22 \pm 0.00^{\mathrm{b}}$ & $37.73 \pm 0.00^{\mathrm{b}}$ & $38.48 \pm 0.00^{\mathrm{b}}$ & $40.96 \pm 0.00^{\mathrm{a}}$ & $39.63 \pm 0.00^{\mathrm{a}}$
\end{tabular}

Values are expressed as mean \pm SD. Values with different superscript letters indicate differences among the groups $(P<0.05)$. Group 1: Normal Control; Group 2: Diabetic Control; Group 3: Standard Drug; Group 4: Morinda lucida Leaf; Group 5: Nauclea latifolia Leaf; Group 6: M. lucida and N. latifolia Leaves.

Table 9. Effect of aqueous extract of M. lucida and N. latifolia leaves on Glutathione peroxidase activities in diabetic rats $(\mathrm{U} / \mathrm{L})$.

\begin{tabular}{l|l|l|l|l|l|l} 
Category & Group 1 & Group 2 & Group 3 & Group 4 & Group 5 & Group 6 \\
\hline Serum & $168.54 \pm 0.01^{\mathrm{a}}$ & $102.28 \pm 0.03^{\mathrm{b}}$ & $114.92 \pm 0.05^{\mathrm{c}}$ & $162.57 \pm 0.02^{\mathrm{a}}$ & $155.65 \pm 0.02^{\mathrm{a}}$ & $121.92 \pm 0.05^{\mathrm{c}}$ \\
\hline Liver & $73.25 \pm 0.01^{\mathrm{a}}$ & $29.82 \pm 0.01^{\mathrm{b}}$ & $98.23 \pm 0.01^{\mathrm{c}}$ & $33.98 \pm 0.01^{\mathrm{b}}$ & $33.72 \pm 0.01^{\mathrm{b}}$ & $47.23 \pm 0.01^{\mathrm{b}}$ \\
\hline Kidney & $271.64 \pm 0.04^{\mathrm{a}}$ & $89.46 \pm 0.01^{\mathrm{b}}$ & $91.15 \pm 0.01^{\mathrm{c}}$ & $95.07 \pm 0.02^{\mathrm{c}}$ & $110.04 \pm 0.02^{\mathrm{d}}$ & $130.15 \pm 0.01^{\mathrm{d}}$
\end{tabular}

Values are expressed as mean \pm SD. Values with different superscript letters indicate differences among the groups $(P<0.05)$. Group 1: Normal Control; Group 2: Diabetic Control; Group 3: Standard Drug; Group 4: Morinda lucida Leaf; Group 5: Nauclea latifolia Leaf; Group 6: M. lucida and N. latifolia Leaves

Transaminases (ALT and AST) are important hepatic markers. Their presence in the serum at high concentration serves as indicators for liver pathology. This is the case in the administration of toxins to experimental animals, where there is a significant increase in these enzymes' serum levels. An increase in the activities of ALT and AST in Alloxan intoxication has earlier been reported [52,53]. Tables 10 and 12 showed similar results in the present study. However, both standard drug and the two plant extracts were able to inhibit changes in ALT and AST activity in experimental animals showing their protective potentials.

The serum aspartate transaminase (AST), alanine transaminase (ALT) and alkaline phosphatase (ALP), and Lactate dehydrogenase (LDH) activities increased, which was an indication of diabetes-induced hepatic parenchymal injury and hepatic dysfunction [54,55] and leakage of these enzymes from the liver cytosol into the bloodstream [55,56]. However, after administering the extracts in Table 10,11, 12, and 13, the serum AST, ALT, and ALP concentrations decreased relatively with leaves of the M. Lucida and $N$. Latifolia extract and the standard drug.

Table 10. Effect of aqueous extract of M. lucida and N. latifolia leaves on Alanine Amino Transferase (ALT) in diabetic rats (U/L).

\begin{tabular}{l|l|l|l|l|l|l} 
Category & Group 1 & Group 2 & Group 3 & Group 4 & Group 5 & Group 6 \\
\hline Serum & $0.25 \pm 0.09^{\mathrm{a}}$ & $2.64 \pm 0.09^{\mathrm{b}}$ & $0.59 \pm 0.04^{\mathrm{c}}$ & $0.35 \pm 0.09^{\mathrm{d}}$ & $1.44 \pm 0.09^{\mathrm{e}}$ & $1.02 \pm 0.09^{\mathrm{d}}$ \\
\hline Liver & $2.54 \pm 0.07^{\mathrm{a}}$ & $0.29 \pm 0.85^{\mathrm{b}}$ & $1.27 \pm 0.25^{\mathrm{c}}$ & $1.25 \pm 0.08^{\mathrm{c}}$ & $1.44 \pm 0.09^{\mathrm{d}}$ & $1.42 \pm 0.09^{\mathrm{d}}$ \\
\hline Kidney & $2.84 \pm 0.09^{\mathrm{a}}$ & $0.34 \pm 0.17^{\mathrm{b}}$ & $1.36 \pm 0.17^{\mathrm{c}}$ & $0.59 \pm 0.09^{\mathrm{d}}$ & $0.68 \pm 0.51^{\mathrm{e}}$ & $0.79 \pm 0.02^{\mathrm{e}}$
\end{tabular}

Values are expressed as mean \pm SD. Values with different superscript letters indicate differences among the groups $(P<0.05)$. Group 1: Normal Control; Group 2: Diabetic Control; Group 3: Standard Drug; Group 4: Morinda lucida Leaf; Group 5: Nauclea latifolia Leaf; Group 6: M. lucida and N. latifolia Leaves. 
Table 11. Effect of aqueous extract of M. lucida and N. latifolia Leaves on Alkaline Phosphatase (ALP) in diabetic rats (U/L).

\begin{tabular}{l|l|l|l|l|l|l} 
Category & Group 1 & Group 2 & Group 3 & Group 4 & Group 5 & Group 6 \\
\hline Serum & $4.14 \pm 1.38^{\mathrm{a}}$ & $9.66 \pm 4.14^{\mathrm{b}}$ & $5.14 \pm 1.38^{\mathrm{c}}$ & $4.14 \pm 1.38^{\mathrm{a}}$ & $6.52 \pm 2.76^{\mathrm{d}}$ & $7.14 \pm 0.00^{\mathrm{d}}$ \\
\hline Liver & $6.90 \pm 1.38^{\mathrm{a}}$ & $5.76 \pm 0.00^{\mathrm{b}}$ & $6.14 \pm 1.38^{\mathrm{c}}$ & $6.76 \pm 0.00^{\mathrm{a}}$ & $7.76 \pm 0.00^{\mathrm{d}}$ & $6.90 \pm 0.00^{\mathrm{a}}$ \\
\hline Kidney & $6.90 \pm 1.38^{\mathrm{a}}$ & $3.14 \pm 1.38^{\mathrm{b}}$ & $6.99 \pm 1.38^{\mathrm{c}}$ & $7.66 \pm 1.38^{\mathrm{d}}$ & $7.76 \pm 0.00^{\mathrm{d}}$ & $8.00 \pm 1.38^{\mathrm{d}}$
\end{tabular}

Values are expressed as mean \pm SD. Values with different superscript letters indicate differences among the groups $(P<0.05)$. Group 1: Normal Control; Group 2: Diabetic Control; Group 3: Standard Drug; Group 4: Morinda lucida Leaf; Group 5: Nauclea latifolia Leaf; Group 6: M. lucida and N. latifolia Leaves.

Table 12. Effect of aqueous extract of M. lucida and N. latifolia leaves on Aspartate Aminotransferase (AST) in

\begin{tabular}{l|l|l|l|l|l|l}
\multicolumn{7}{c}{ diabetic rats (U/L). } \\
Category & Group 1 & Group 2 & Group 3 & Group 4 & Group 5 & Group 6 \\
\hline Serum & $34.31 \pm 0.17^{\mathrm{a}}$ & $216.69 \pm 0.17^{\mathrm{b}}$ & $18.10 \pm 0.17^{\mathrm{c}}$ & $23.97 \pm 0.17^{\mathrm{d}}$ & $27.76 \pm 0.17^{\mathrm{d}}$ & $26.69 \pm 0.17^{\mathrm{d}}$ \\
\hline Liver & $195.35 \pm 0.17^{\mathrm{a}}$ & $68.69 \pm 0.17^{\mathrm{a}}$ & $219.14 \pm 0.17^{\mathrm{b}}$ & $187.41 \pm 0.17^{\mathrm{b}}$ & $285.69 \pm 0.17^{\mathrm{ab}}$ & $191.90 \pm 0.17^{\mathrm{a}}$ \\
\hline Kidney & $180.17 \pm 0.17^{\mathrm{a}}$ & $100.55 \pm 0.17^{\mathrm{b}}$ & $171.90 \pm 0.17^{\mathrm{c}}$ & $169.48 \pm 0.17^{\mathrm{a}}$ & $191.48 \pm 0.17^{\mathrm{d}}$ & $172.07 \pm 0.17^{\mathrm{c}}$
\end{tabular}

Values are expressed as mean \pm SD. Values with different superscript letters indicate differences among the groups $(P<0.05)$. Group 1: Normal Control; Group 2: Diabetic Control; Group 3: Standard Drug; Group 4: Morinda lucida Leaf; Group 5: Nauclea latifolia Leaf; Group 6: M. lucida and N. latifolia Leaves.

Table 13. Effect of aqueous extract of M. lucida and N. latifolia leaves on Lactate Dehydrogenase (LDH) in

\begin{tabular}{l|l|l|l|l|l|l} 
Category & Group 1 & Group 2 & Group 3 & Group 4 & Group 5 & Group 6 \\
\hline Serum & $145.23 \pm 0.48^{\mathrm{a}}$ & $290.46 \pm 0.96^{\mathrm{b}}$ & $145.23 \pm 0.48^{\mathrm{a}}$ & $145.23 \pm 0.48^{\mathrm{a}}$ & $277.74 \pm 0.96^{\mathrm{b}}$ & $193.64 \pm 0.00^{\mathrm{c}}$ \\
\hline Liver & $196.82 \pm 0.00^{\mathrm{a}}$ & $193.64 \pm 0.00^{\mathrm{a}}$ & $96.82 \pm 0.00^{\mathrm{b}}$ & $102.05 \pm 0.48^{\mathrm{b}}$ & $151.64 \pm 0.96^{\mathrm{ab}}$ & $120.46 \pm 0.00^{\mathrm{c}}$ \\
\hline Kidney & $145.23 \pm 0.48^{\mathrm{a}}$ & $187.28 \pm 0.19^{\mathrm{b}}$ & $242.05 \pm 0.48^{\mathrm{c}}$ & $145.23 \pm 0.48^{\mathrm{a}}$ & $222.05 \pm 0.48^{\mathrm{d}}$ & $193.64 \pm 0.96^{\mathrm{b}}$
\end{tabular}

Values are expressed as mean \pm SD. Values with different superscript letters indicate differences among the groups $(P<0.05)$. Group 1: Normal Control; Group 2: Diabetic Control; Group 3: Standard Drug; Group 4: Morinda lucida Leaf; Group 5: Nauclea latifolia Leaf; Group 6: M. lucida and N. latifolia Leaves.

Table 14. Effect of aqueous extract of M. lucida and N. latifolia Leaves on Total cholesterol in diabetic rats

\begin{tabular}{l|l|l|l|l|l|l} 
Category & Group 1 & Group 2 & Group 3 & Group 4 & Group 5 & Group 6 \\
\hline Serum & $1.33 \pm 0.01^{\mathrm{a}}$ & $6.92 \pm 0.01^{\mathrm{b}}$ & $3.52 \pm 0.08^{\mathrm{c}}$ & $3.27 \pm 0.08^{\mathrm{c}}$ & $2.05 \pm 0.01^{\mathrm{a}}$ & $1.02 \pm 0.01^{\mathrm{a}}$ \\
\hline Liver & $0.53 \pm 0.01^{\mathrm{a}}$ & $2.92 \pm 0.01^{\mathrm{b}}$ & $0.97 \pm 0.01^{\mathrm{c}}$ & $0.99 \pm 0.01^{\mathrm{c}}$ & $1.20 \pm 0.01^{\mathrm{d}}$ & $1.40 \pm 0.01^{\mathrm{d}}$ \\
\hline Kidney & $0.77 \pm 0.01^{\mathrm{a}}$ & $2.45 \pm 0.01^{\mathrm{b}}$ & $1.18 \pm 0.01^{\mathrm{c}}$ & $0.23 \pm 0.01^{\mathrm{d}}$ & $1.58 \pm 0.01^{\mathrm{c}}$ & $1.20 \pm 0.01^{\mathrm{c}}$
\end{tabular}

Values are expressed as mean \pm SD. Values with different superscript letters indicate differences among the groups $(P<0.05)$. Group 1: Normal Control; Group 2: Diabetic Control; Group 3: Standard Drug; Group 4: Morinda lucida Leaf; Group 5: Nauclea latifolia Leaf; Group 6: M. lucida and N. latifolia Leaves.

Table 15. Effect of aqueous extract of M. lucida and N. latifolia leaves on High-Density Lipoprotein cholesterol in diabetic rats $(\mathrm{mg} / \mathrm{dL})$.

\begin{tabular}{l|l|l|l|l|l|l} 
Category & Group 1 & Group 2 & Group 3 & Group 4 & Group 5 & Group 6 \\
\hline Serum & $942.57 \pm 0.68^{\mathrm{a}}$ & $519.60 \pm 0.68^{\mathrm{b}}$ & $937.84 \pm 1.35^{\mathrm{a}}$ & $929.73 \pm 0.00^{\mathrm{a}}$ & $541.76 \pm 0.00^{\mathrm{b}}$ & $720.35 \pm 0.68^{\mathrm{c}}$ \\
\hline Liver & $125.00 \pm 0.68^{\mathrm{a}}$ & $58.78 \pm 0.68^{\mathrm{b}}$ & $170.95 \pm 0.68^{\mathrm{c}}$ & $169.60 \pm 0.68^{\mathrm{d}}$ & $126.35 \pm 0.68^{\mathrm{e}}$ & $126.35 \pm 0.68^{\mathrm{e}}$ \\
\hline Kidney & $260.14 \pm 0.68^{\mathrm{a}}$ & $106.08 \pm 0.68^{\mathrm{b}}$ & $180.14 \pm 0.68^{\mathrm{c}}$ & $165.54 \pm 0.68^{\mathrm{c}}$ & $121.62 \pm 0.00^{\mathrm{d}}$ & $156.35 \pm 0.68^{\mathrm{c}}$
\end{tabular}

Values are expressed as mean \pm SD. Values with different superscript letters indicate differences among the groups $(P<0.05)$. Group 1: Normal Control; Group 2: Diabetic Control; Group 3: Standard Drug; Group 4: Morinda lucida Leaf; Group 5: Nauclea latifolia Leaf; Group 6: M. lucida and N. latifolia Leaves.

Table 16. Effect of aqueous extract of Morinda lucida and Nauclea latifolia Leaves on Low Density Lipoprotein - cholesterol in diabetic rats $(\mathrm{mg} / \mathrm{dL})$.

\begin{tabular}{l|l|l|l|l|l|l} 
Category & Group 1 & Group 2 & Group 3 & Group 4 & Group 5 & Group 6 \\
\hline Serum & $519.6 \pm 0.68^{\mathrm{a}}$ & $1137.84 \pm 1.35^{\mathrm{b}}$ & $401.76 \pm 0.00^{\mathrm{c}}$ & $441.76 \pm 0.00^{\mathrm{d}}$ & $515.95 \pm 0.00^{\mathrm{e}}$ & $470.87 \pm 0.68^{\mathrm{f}}$ \\
\hline Liver & $58.78 \pm 0.68^{\mathrm{a}}$ & $270.95 \pm 0.68^{\mathrm{b}}$ & $92.57 \pm 0.68^{\mathrm{c}}$ & $169.6 \pm 0.68^{\mathrm{d}}$ & $126.35 \pm 0.68^{\mathrm{e}}$ & $134.00 \pm 0.68^{\mathrm{e}}$ \\
\hline Kidney & $106.08 \pm 0.68^{\mathrm{a}}$ & $160.14 \pm 0.68^{\mathrm{b}}$ & $101.62 \pm 0.00^{\mathrm{c}}$ & $105.54 \pm 0.68^{\mathrm{d}}$ & $121.62 \pm 0.00^{\mathrm{e}}$ & $130.55 \pm 0.00^{\mathrm{e}}$
\end{tabular}

Values are expressed as mean \pm SD. Values with different superscript letters indicate differences among the groups $(P<0.05)$. Group 1: Normal Control; Group 2: Diabetic Control; Group 3: Standard Drug; Group 4: Morinda lucida Leaf; Group 5: Nauclea latifolia Leaf; Group 6: Morinda Lucida and Nauclea Latifolia Leaves.

This persistent hyperglycemia was characterized by corresponding high serum TG, TC, LDL-C (Tables 14, 15, 16, and 17). These biochemical alterations recorded in this study is in 
complete agreement with earlier reported studies on metabolic abnormalities in diabetesinduced by alloxan $[57,58]$.

Table 17. Effect of aqueous Leaves extracts of M. lucida and N. latifolia on Triglyceride in diabetic rats. (U/L)

\begin{tabular}{l|l|l|l|l|l|l} 
Category & Group 1 & Group 2 & Group 3 & Group 4 & Group 5 & Group 6 \\
\hline Serum & $5.33 \pm 0.01^{\mathrm{a}}$ & $17.75 \pm 0.00^{\mathrm{b}}$ & $8.76 \pm 0.01^{\mathrm{c}}$ & $6.05 \pm 0.01^{\mathrm{d}}$ & $10.82 \pm 0.14^{\mathrm{e}}$ & $5.50 \pm 0.14^{\mathrm{e}}$ \\
\hline Liver & $16.21 \pm 0.01^{\mathrm{a}}$ & $28.71 \pm 0.01^{\mathrm{b}}$ & $20.42 \pm 0.01^{\mathrm{c}}$ & $17.10 \pm 0.01^{\mathrm{d}}$ & $22.99 \pm 0.01^{\mathrm{e}}$ & $24.06 \pm 0.01^{\mathrm{e}}$ \\
\hline Kidney & $4.14 \pm 0.01^{\mathrm{a}}$ & $6.60 \pm 0.01^{\mathrm{b}}$ & $3.86 \pm 0.01^{\mathrm{c}}$ & $4.20 \pm 0.0^{\mathrm{d}}$ & $5.21 \pm 0.01^{\mathrm{e}}$ & $3.92 \pm 0.01^{\mathrm{e}}$
\end{tabular}

Values are expressed as mean $\pm \mathrm{SD}$. Values with different superscript letters indicate differences among the groups $(P<0.05)$. Group 1: Normal Control; Group 2: Diabetic Control; Group 3: Standard Drug; Group 4: Morinda lucida Leaf; Group 5: Nauclea latifolia Leaf; Group 6: M. lucida and N. latifolia Leaves

\section{Conclusions}

An in silico study has shown that 4 constituents of Nauclea latifolia leaf extracts (2-Op- methylphenyl- 1-thio- $\beta$-d-glucoside, 3-tosylsedoheptulose, 4-benzyloxy-6 -hydroxymethyl - tetrahydropyran-2,3,5 -triol, and vitamin E) could inhibit iipeptidyl peptidase IV (DPP-IV), which is a pharmacotherapeutic target in type 2 diabetes [59]. It was reported that dichloromethane extract of $M$. lucida showed high inhibitory capacity on $\alpha$-amylase and $\beta$ glucosidase activities [60]. The study has shown the protective role of $125-500 \mathrm{mg} / \mathrm{kg} / \mathrm{day}$ of Morinda lucida aqueous stem bark extract in chronic hyperglycemia-associated renal and hepatic dysfunctions in the experimental diabetes model, which was mediated via antioxidant and free radical scavenging activities [61].

The ability of the aqueous leaf extracts of Morinda lucida and Nauclea latifolia to decrease hyperglycemic rats' blood glucose towards normal confirms its antidiabetic activity. The leaf extracts of both plants also inhibited diabetic complications by preventing an alteration in plasma concentration of lipoprotein, triglyceride, cholesterol, and AST and ALT activities. The aqueous extract of the two plants possesses good antioxidant potentials by inhibiting the collapse of antioxidant defense induced by alloxan. The bioactive substances present in this plant leaves extract might be responsible for their medicinal and antioxidant properties.

\section{Funding}

This research received no external funding.

\section{Acknowledgments}

I sincerely acknowledge the moral and material support by Mrs. W.G. Akinlolu, technical and administrative support by Mr. T.H. Fatoki, and Mr. Seun Arowolo for materials used for the experiment.

\section{Conflicts of Interest}

The authors declare no conflict of interest.

\section{References}

1. World Health Organization. Classification of diabetes mellitus. Geneva: Licence: CC BY-NC-SA 3.0IGO. 2019.

2. Weeratunga, P.; Jayasinghe, S.; Perera, Y.; Jayasena, G.; Jayasinghe, S. Per capita sugar consumption and prevalence of diabetes mellitus - global and regional associations. BMC Public Health 2014, 14, 186-191, https://doi.org/10.1186/1471-2458-14-186. 
3. Abdullah, N.; Murad, N.A.A.; Attia, J.; Oldmeadow, C.; Kamaruddin, M.A.; Jalal, N.A.; Ismail, N.; Jamal, R.; Scott, R.J.; Holliday, E.G. Differing Contributions of Classical Risk Factors to Type 2 Diabetes in MultiEthnic Malaysian Populations. Int J Environ Res Public Health 2018, 15, https://doi.org/10.3390/ijerph15122813.

4. Shaw, J.E.; Sicree, R.A.; Zimmet, P.Z. Global estimates of the prevalence of diabetes for 2010 and 2030 ; Diabetes Research and Clinical Practice 2010, 87, 4-14, https://doi.org/10.1016/j.diabres.2009.10.007.

5. Akhtar, S.; Nasir, J.A.; Sarwar, A.; Nasr, N.; Javed, A.; Majeed, R.; Salam, M.A.; Billah, B. Prevalence of diabetes and pre-diabetes in Bangladesh: a systematic review and meta-analysis. BMJ Open 2020, 10, https://doi.org/10.1136/bmjopen-2019-036086.

6. Liu, C.; Li, X.; Lin, M.; Zheng, L.; Chen, X. A cross-sectional study on diabetes epidemiology among people aged 40 years and above in Shenyang, China. Sci Rep 2020, 10, https://doi.org/10.1038/s41598-020-74889$\mathrm{x}$.

7. World Health Organization. Global Burden of Diabetes. In: Global Report on Diabetes. Paris. 2016, Available at: https://apps.who.int/iris/rest/bitstreams/909883/retrieve.

8. Katsiki, N.; Athyros, V.G.; Mikhailidis, D.P. Non-alcoholic fatty liver disease in patients with type 2 diabetes mellitus: effects of statins and antidiabetic drugs. J Diabetes Complications 2017, 31, 521-52, https://doi.org/10.1016/j.jdiacomp.2016.12.006.

9. American Diabetes Association. Standards of Medical Care in Diabetes - 2017. Diabetes Care 2017, 40(Suppl.1), 51-52.

10. Sheehan, M.T. Current therapeutic options in type 2 diabetes mellitus: a practical approach. J. Clin. Med. Res. 2003, 1, 189-200, https://doi.org/10.3121/cmr.1.3.189.

11. Thompson, P.L.; Davis, T.M.E. Cardiovascular effects of glucose lowering therapies for type 2 diabetes: New drugs in perspective. Clin Ther 2017, 39, 1012-1025, https://doi.org/10.1016/j.clinthera.2016.10.008.

12. Wang, Q.; Wang, J.; Lin, H.; Huo, X.; Zhu, Q.; Zhang, M. Relationship between fat mass and obesityassociated gene expression and type 2 diabetes mellitus severity. Exp Ther Med 2018, 15, 2917-2921, https://doi.org/10.3892/etm.2018.5752.

13. Danaei, G.; Finucane, M.M.; Lu, Y.; Singh, G.M.; Cowan, M.J.; Paciorek, C.J.; Lin, J.K.; Farzadfar, F.; Khang, Y.-H.; Stevens, G.A.; Rao, M.; Ali, M.K.; Riley, L.M.; Robinson, C.A.; Ezzati, M. National, regional, and global trends in fasting plasma glucose and diabetes prevalence since 1980: systematic analysis of health examination surveys and epidemiological studies with 370 country-years and 2.7 million participants. The Lancet 2011, 378, 31-40, https://doi.org/10.1016/s0140-6736(11)60679-x.

14. Ton, T.T.; Tran, A.T.N.; Do, I.T.; Nguyen, H.; Nguyen, T.T.B.; Nguyen, M.T.; Ha, V.A.B.; Tran, A.Q.; Hoang, H.K.; Tran, B.T. Trends in prediabetes and diabetes prevalence and associated risk factors in Vietnamese adults. Epidemiol Health 2020, 42, https://doi.org/10.4178/epih.e2020029.

15. Aung, W.P.; Bjertness, E.; Htet, A.S.; Stigum, H.; Kjøllesdal, M.K.R. Trends in Diabetes Prevalence, Awareness, Treatment and Control in Yangon Region, Myanmar, Between 2004 and 2014, Two CrossSectional Studies. Int J Environ Res Public Health 2019, 16, https://doi.org/10.3390/ijerph16183461.

16. Rotenstein, L.S.; Kozak, B.M.; Shivers, J.P.; Yarchoan, M.; Close, J.; Close, K.L. The ideal diabetes therapy: what will it look like? How close are we? Clin. Diabetes 2012, 30, 44-53, https://doi.org/10.2337/diaclin.30.2.44.

17. Gupta, P.; Bala, M.; Gupta, S.; Dua, A.; Dabur, R.; Injeti, E.; Mittal, A. Efficacy and risk profile of antidiabetic therapies: Conventional vs traditional drugs - A mechanistic revisit to understand their mode of action. Pharmacol. Res. 2016, 113, 636-667, https://doi.org/10.1016/j.phrs.2016.09.029.

18. Adeneye A.A., Amole O.O.; Adeneye A.K. Hypoglycemic and hypocholesterolemic activities of the aqueous leaf and seed extract of Phyllanthus amarus in mice. Fitoterapia 2006, 77, 511- 514, https://doi.org/10.1016/j.fitote.2006.05.030.

19. Adeneye, A.A.; Agbaje, E.O. Pharmacological evaluation of oral hypoglycemic and antidiabetic effects of fresh leaves ethanol extract of Morinda lucida Benth. in normal and alloxan-induced diabetic rats. Afr $J$ Biomed Res 2008, 11, 65-71, https://doi.org/10.4314/ajbr.v11i1.50669.

20. Adebayo, J.O.; Krettli, A.U. Potential antimalarials from Nigerian plants: a review. J Ethnopharmacol 2011, 133, 289-302, https://doi.org/10.1016/j.jep.2010.11.024.

21. Abdulkareem, A.O.; Igunnu, A.; Ala, A.A.; Olatunji , L.A. Leaf extract of Morinda lucida improves pancreatic beta-cell function in alloxan-induced diabetic rats, Egyptian Journal of Basic and Applied Sciences 2019, 6, 73-81, https://doi.org/10.1080/2314808X.2019.1666501.

22. Chokki, M.; Cudălbeanu, M.; Zongo, C.; Dah-Nouvlessounon, D.; Ghinea, I.O.; Furdui, B.; Raclea, R.; Savadogo, A.; Baba-Moussa, L.; Avamescu, S.M.; Dinica, R.M.; Baba-Moussa, F. Exploring Antioxidant and Enzymes (A-Amylase and B-Glucosidase) Inhibitory Activity of Morinda lucida and Momordica charantia Leaves from Benin. Foods 2020, 9, https://doi.org/10.3390/foods9040434.

23. Adewole, K.E.; Ishola, A.A. Phytosterols and triterpenes from Morinda lucida Benth (Rubiaceae) as potential inhibitors of anti-apoptotic BCL-XL, BCL-2, and MCL-1: an in-silico study. J Recept Signal Transduct Res. 2019, 39, 87-97, https://doi.org/10.1080/10799893.2019.1625062. 
24. Balogun, S.T.; Sandabe, U.K.; Okon, K.O.; Akanmu, A.O.; Fehintola, F.A. Malaria burden and pre-hospital medication among subjects with malaria in Maiduguri, Northeast Nigeria. Heliyon 2019, 5, https://doi.org/10.1016/j.heliyon.2019.e02280.

25. Oladeji, O.S.; Oluyori, A.P.; Bankole, D.T.; Afolabi, T.Y. Natural Products as Sources of Antimalarial Drugs: Ethnobotanical and Ethnopharmacological Studies. Scientifica (Cairo) 2020, 2020, https://doi.org/10.1155/2020/7076139.

26. Adewole, K.E.; Igunnu, A.; Adebayo, J.O. Effects of Cysteine-Stabilised Peptide Fraction of Aqueous Extract of Morinda lucida Leaf on Selected Cardiovascular Disease Indices in Mice. Indian J Clin Biochem 2019, 34, 427-435, https://doi.org/10.1007/s12291-018-0776-4

27. Fakoya, A.; Owojuyigbe, O.S.; Fakoya, S.; Adeoye, S.O. Possible antimicrobial activity of Morinda lucida stem bark, leaf and root extracts. Afr J Biotechnol 2014, 13, 471-475, https://doi.org/10.5897/AJB10.1472.

28. Nworgu, Z.A.M.; Onwukaeme, D.N.; Afolayan, A.J.; Ammeachina, F.C.; Ayinde, B.A. Preliminary studies of blood pressure lowering effect of Nauclea latifolia in rats. African J Pharm Pharmacol 2008, 2, 037-041.

29. Deeni, Y.Y.; Hussain, H.S.N. Screening for antimicrobial activity and for alkaloids of Nauclea latifolia. J. Ethnopharmacol. 1991, 35, 91-96, https://doi.org/10.1016/0378-8741(91)90137-3.

30. Iheagwam, F.N.; Israel, E.N.; Kayode, K.O.; DeCampos, O.C.; Ogunlana, O.O.; Chinedu, S.N. Nauclea latifolia Sm. Leaf Extracts Extenuates Free Radicals, Inflammation, and Diabetes-Linked Enzymes. Oxid Med Cell Longev 2020, 2020, https://doi.org/10.1155/2020/5612486.

31. Bankeu, J.J.K.; Kagho, D.U.K.; Fongang, Y.S.F.; Toghueo, R.M.K.; Mba'ning, B.M.; Feuya, G.R.T.; Fekam F.B.; Tchouankeu, J.C.; Ngouela, S.A.; Sewald, N.; Lenta, B.N.; Ali, M.S. Constituents from Nauclea latifolia with Anti-Haemophilus influenzae Type b Inhibitory Activities. J Nat Prod 2019, 82, 2580-2585, https://doi.org/10.1021/acs.jnatprod.9b00463.

32. Aggrey, M.O.; Li, H.H.; Wang, W.Q.; Wang, Y.; Xuan, L.J. Indole alkaloid from Nauclea latifolia promotes LDL uptake in HepG2 cells by inhibiting PCSK9. Phytomedicine 2019, 55, 264-268, https://doi.org/10.1016/j.phymed.2018.06.041.

33. Brichacek, A.L.; Brown, C.M. Alkaline phosphate: a potential biomarker for Stroke and implications for treatment. Metab. Brain Dis 2019, 34, 3-19, https://doi.org/10.1007/s11011-018-0322-3.

34. Molehin, O.R.; Oloyede, O.I.; Adefegha, S.A. Streptozotocin-induced diabetes in rats: effects of White Butterfly (Clerodendrum volubile) leaves on blood glucose levels, lipid profile and antioxidant status. Toxicol Mech Methods 2018, 28, 573-586, https://doi.org/10.1080/15376516.2018.1479476

35. Igile, G.O.; Iwara, I.A.; Mgbeje, B.I.A.; Uboh, F.E.; Ebong, P.E. Phytochemical Screening to Validate Nutrient Composition of Vernonia calvaona Hook (Asterecea): A green-leafy in Nigeria. Journal of Food Research 2013, 2, http://dx.doi.org/10.5539/jfr.v2n6p1.

36. Baggio, S.R.; Bragagnolo, N. The effect of heat treatment on the cholesterol oxides, cholesterol, total lipid and fatty acid contents of processed meat products. Food Chem 2006, 95, 611-9, https://doi.org/10.1016/j.foodchem.2005.01.037.

37. Steghens, J.; Van Kappel, A.L.; Denis, I.; Collombel, C. Diaminonaphtalene, a new highly specific regent for HPLC-UV measurement of total and free malondialdehydein human plasma or serum. Free Radic Biol Med 2001, 31, 242-249, https://doi.org/10.1016/s0891-5849(01)00578-0.

38. Hultqvist, M.; Hegbrant, J.; Nilsson-Thorell, C.; Lindholm, T.; Nilsson, P.; Lindén, T.; Hultqvist-Bengtsson, U. Plasma concentrations of vitamin $\mathrm{C}$, vitamin $\mathrm{E}$ and/or malondialdehyde as markers of oxygen free radical production during hemodialysis. Clinical nephrology 1997, 47, 37-46.

39. Al-Attar, A.M. Hypolipidemic effects of coenzyme Q10 in experimentally induced hypercholesterolemic model in female rats. American Journal of Pharmacology and Toxicology 2010, 5, 14-23, https://doi.org/10.3844/ajptsp.2010.14.23

40. Daay, F.; Lattanzio, V. Recent advances in polyphenol research. Blackwell Publishing Ltd. Volume 1, 2008.

41. Gidado, A.; Ameh, D.A.; Atawodi, S.E.; Ibrahim, S. Hypoglycaemic activity of Nauclea latifolia Sm. (Rubiaceae) in experimental animals. Afr J Tradit Complement Altern Med 2008, 5, 201-208, https://dx.doi.org/10.4314\%2Fajtcam.v5i2.31274.

42. Olajide, O.A.; Awe, S.O.; Makinde, J.M.; Morebise, O. Evaluation of the antidiabetic property of Morinda lucida leaves in streptozotocin-diabetic rats. J. Pharm. Pharmacol 1999, 51, 1321-1324.

43. Tiong, S.H.; Looi, C.Y.; Hazni, H.; Arya, A.; Paydar, M.; Wong, W.F.; Cheah, S.C.; Mustafa, M.R.; Awang, K. Antidiabetic and antioxidant properties of alkaloids from Catharanthus roseus (L.) G. Don. Molecules 2013, 18, 9770-84, https://doi.org/10.3390/molecules 18089770

44. Lawal, H.O.; Etatuvie, S.O.; Fawehinmi, A.B. Ethnomedicinal and Pharmacological properties of Morinda lucida" Journal of Natural Products 2012, 5, 93-99.

45. Yadav, U.C.S.; Moorthy, K.; Baquer, N.Z. Combined treatment of sodium orthovanadate and Momordica charantia fruit extract prevents alterations in lipid profile and lipogenic enzymes in alloxan diabetic rats. Molecular and Cellular Biochemistry 2005, 268, 111-120, https://doi.org/10.1007/s11010-005-3703-y

46. Qia, X.Y.; Chen, W.J.; Zhang, L.Q.; Xie, B.J. Mogrosides extract from Siraitiagrosvenori scavenges free radicals in vitro and lowers oxidative stress, serum glucose, and lipid levels in alloxan-induced diabetic mice. Nutr. Res. 2008, 28, 278-284, https://doi.org/10.1016/j.nutres.2008.02.008. 
47. Kröncke, K.D.; Fehsel, K.; Summer, A.; Rodriguez, M.L.; Kolb-Bachofen, V. Nitric oxide generation during cellular metabolization of the diabetogenic N-methyl-nitroso-urea: Streptozotocin contributes to islet cell DNA damage. Biol. Chem. 1995, 376, 179-183, https://doi.org/10.1515/bchm3.1995.376.3.179

48. Bedoya, F.I.; Solano, F.; Lucas, M. N-monomethyl-arginine and nicotinamide prevent streptozotocininduced double strand DNA break formation in pancreatic rat islets. Experientia 1996, 52, 344-347, https://doi.org/10.1007/bf01919538.

49. Umamaheswari, M.; Chatterjee, T.K. Effect of the fractions of Cocciniagrandis on ethanol-induced cerebral

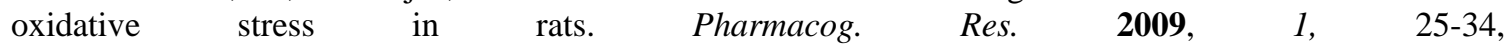
http://www.phcogres.com/text.asp?2009/1/1/25/58144.

50. Ogunlana, O.E.; Ogunlana, O.; Farombi, O.E. Morinda lucida: Antioxidant and reducing activities of crude methanolic stem bark extract. Adv. Natl. Appl. Sci. 2008, 2, 49-54, http://eprints.covenantuniversity.edu.ng/id/eprint/409.

51. Youdim, K.A.; Joseph, J.A. A Possible emerging role of phytochemical in improving age-related neurological dysfunctions-a multiplicity of effects. Free Rad. Biol. Med. 2001, 30, 583-594, https://doi.org/10.1016/s0891-5849(00)00510-4

52. Mobasher, A.; Sairah, H.K.; Afroze, M. Protective effect of crude Curcuma longa and its methanolic extract in alloxanized rabbits. Pak. J. Pharm. Sci. 2014, 27, 121-128.

53. Sellamuthu, P.S.; Arulselvan, P.; Fakurazi, S.; Kandasamy, M. Beneficial effects of mangiferin isolated from Salacia chinensis on biochemical and hematological parameters in rats with streptozotocin induced diabetes. Pak. J. Pharm. Sci 2014, 27, 161-167.

54. Nabi, S.A.; Kasetti, R.B.; Sirasanagandla, S.; Tilak, T.K.; Kumar, M.V.; Rao, C.A. Antidiabetic and antihyperlipidemic activity of Piper longum root aqueous extract in STZ induced diabetic rats. BMC Complement Altern Med 2013, 13, https://doi.org/10.1186/1472-6882-13-37

55. El-Demerdash, F.M.; Yousef, M.I.; El-Naga, N.I. Biochemical study on the hypoglycemic effects of onion and garlic in alloxan-induced diabetic rats. Food Chem Toxicol 2005, 43, 57-63, https://doi.org/10.1016/j.fct.2004.08.012.

56. Kumar, V.; Abbas, A.K.; Fausto, N.; Robbins, SL.; Cotran, R.S. Robbins and Cotran pathologic basis of disease. 7th ed.. Philadelphia: Elsevier Saunders, 2005.

57. Ashok-Kumar, B.S.; Lakshman, K.; Jayaveea, K.N.; Sheshadri-Shekar, D.; Saleemulla, K.; Thippeswamy, B.S.; Veerapur, V.P. Antidiabetic, anti-hyperlipidemic and antioxidant activities of methanolic extract of Amaranthus viridis Linn. In alloxan-induced diabetic rats. Exp Toxicol Pathol 2012, 64, 75-79, https://doi.org/10.1016/j.etp.2010.06.009

58. Sreelatha, S.; Inbavalli, R. Antioxidant, Antihyperglycemic and anti-hyperlipidemic effects of Coriandrum sativum leaf and stem in alloxan-induced diabetic rats. J Food Sci 2012, 77, T119-123.

59. Iheagwam, F.N.; Ogunlana, O.O.; Chinedu, S.N. Model Optimization and In Silico Analysis of Potential Dipeptidyl Peptidase IV Antagonists from GC-MS Identified Compounds in Nauclea latifolia Leaf Extracts. Int J Mol Sci. 2019, 20, https://doi.org/10.3390/ijms20235913

60. Chokki, M.; Cudălbeanu, M.; Zongo, C.; Dah-Nouvlessounon, D.; Ghinea, I.O.; Furdui, B.; Raclea, R.; Savadogo, A.; Baba-Moussa, L.; Avamescu, S.M.; Dinica, R.M.; Baba-Moussa, F. Exploring Antioxidant and Enzymes (A-Amylase and B-Glucosidase) Inhibitory Activity of Morinda lucida and Momordica charantia Leaves from Benin. Foods 2020, 9, https://doi.org/10.3390/foods9040434

61. Adeneye, A.A.; Olagunju, A.J.; Babatunde, O.; Oluyemi, O.; Awosope, O.; Oyekunle, G.; Ayuba, H.; Omoregie, O.; Omole, O. Morinda lucida Aqueous Stem Bark Extract Ameliorates Hepato-Renal Dysfunctions in Experimental Diabetes Model. Niger J Physiol Sci 2019, 34, 33-42. 